\title{
SKILLS TRAINING MODEL FOR STUDENTS AS REQUIREMENTS OF INDUSTRIAL REVOLUTION 4.0
}

\author{
Nguyen Phuong Lan ${ }^{1 *}$, Huynh Cong $\mathrm{Du}^{2}$ \\ 1 Faculty of Tourism and Foods, Ho Chi Minh City University of Food Industry (HUFI), Vietnam \\ Email: lannp@hufi.edu.vn \\ 2 Department of Psychology, University of Labour and Social Affairs (ULSA2), Ho Chi Minh City, Vietnam \\ Email: duhc@ldxh.edu.vn \\ * Corresponding Author
}

Article Info:
Article history:
Received date: 21.07 .2019
Revised date: 29.07 .2019
Accepted date: 03.05 .2020
Published date: 10.06 .2020
To cite this document:
Nguyen, P. L., \& Huynh, C. D
(2020). Skills Training Model for
Student as Requirements of Industrial
4.0. International Journal of
Innovation and Industrial Revolution,
2 (3), 01-14.

DOI: $10.35631 /$ IJIREV.23001

\begin{abstract}
:
The study has two objectives: 1) to provide an overview of the impact of the fourth industrial revolution and 2). Based on the overview, to propose a training model of skills to help students adapt to future work that machines and technology cannot replace people in this revolution. The proposed model includes three skills for students: Complex problem solving, critical thinking, and creativity skills. The model consists of 2 modules with 6 sessions. Each session is expected to last in 60-90 minutes. This study is significant for students, lecturers, and vocational instructors in particular as well as universities, colleges, and vocational training centers in general.
\end{abstract}

Keywords:

Industry 4.0, Complex Problem-Solving Skill, Critical Thinking Skill, Creativity Skill

\section{Introduction}

The Industry 4.0 concept was first presented in 2011 at the Hannover Technology Fair in the Federal Republic of Germany. By 2012, the term was used for leading German industry researchers and associations to improve management and manufacturing processes in industries through "computerization". On January 20, 2016, the World Economic Forum opened with the theme "Mastering the Fourth Industrial Revolution". Since then, the term has been widely used around the world and is widely mentioned in the media.

According to Klaus Schwab (2016), the fourth industrial revolution will have a profound and multi-faceted impact on the world economy in the years to come, which can fundamentally change the mode of production, business and market labor, and it is hard to predict these changes. No matter we accept or not, the education system will be affected by this revolution Copyright $\odot$ GLOBAL ACADEMIC EXCELLENCE (M) SDN BHD - All rights reserved 
(Priya Sharma, 2019). For this reason, this paper sets out two main goals: 1) to provide an overview of impact of the fourth industrial revolution on higher education and its requirements for skills training for students; and 2). Based on the overview, to propose a skills training model to help students adapt to future work that machines and technology cannot replace people in this revolution.

\section{Literature Review}

\section{Fourth Industrial Revolution 4.0}

The First Industrial Revolution began in the 18th century through the use of steam power and mechanization of production; the second in the 19th century through the discovery of electricity and assembly line production; the third in the 20th century through partial automation using memory-programmable controls and computers. We are currently implementing the Fourth Industrial Revolution which is characterized by the application of information and communication technologies to industry and is also known as Industry 4.0 and built on the developments of the Third Industrial Revolution (Egham, 2015).

The basic concept was first presented at the Hannover fair in the year of 2011. Since its introduction, Industry 4.0 is in Germany a common discussion topic in research, academic and industry communities at many different occasions. The main idea is to exploit the potentials of new technologies and concepts such as: 1) availability and use of the internet and IoT; 2) integration of technical processes and business processes in the companies; 3) digital mapping and virtualization of the real world; 4) 'Smart' factory including 'smart' means of industrial production; and 5) 'smart' products (Andreja Rojko, 2017; Đào Quang Vinh, 2017). Industry 4.0 is expected to bring about more changes compared to the previous three industrial revolutions, but the focus is on the development of internet of things, artificial intelligence, 3D printing technology, automation, recycled energy. Artificial intelligence will replace some future work. According to futurists, this will happen between 2029-2050 and even earlier, and it affects almost all aspects of life including society, economy, culture, cooperation and labor market.

In the previous industrial revolutions, changes in work, in cooperation and in communication that allow workers to adapt and integrate while the change of industry 4.0 this time is said to be very difficult and its effects are unpredictable, especially in the field of employment. The problem in the future is not the lack of jobs, but of skills to meet the demands that new work requires. Therefore, education have no exception but to have to reinvent itself quickly by stepping out of the cover, enclosed space and creating suitable contexts for students to have a chance to prepares for future work (Scientix, 2017). According to Nguyen Cuc (2017), the industry 4.0 places higher education in front of new challenges. Universities may not have anticipated the skills that the labor market needs. The training and research activities of traditional methodological universities will face drastic changes in both thinking, knowledge, skills and methods. This rapid change of technology requires education to provide learners with new pattern of thinking, new skills, creativity, and adaptation to the change brought about by the industry 4. This is a big challenge, especially in the context of Vietnam where higher education has revealed many limitations, both the foundation and development factors.

\section{The Fourth Industrial Revolution's Requirements for Skills Training}

According to a report at the World Economic Forum (WEF), the key to successful work in the future is that workers need a new set of skills. According to the Forum, five years from 2015 to 2020 , more than one-third (35\%) of the skills considered important in the current labor force 
will change. By 2020, the Fourth Industrial Revolution will bring us groundbreaking changes such as internet of things, artificial intelligence, and 3D printing technology. Artificial intelligence will replace some future work. These developments will change the way we live and work. Some jobs will disappear, others will grow. What is certain is that the future workforce will need to align its skillset to keep pace (World Economic Forum, 2016). The WEF has also released a set of 10 essential skills by 2020 .

\begin{tabular}{ll}
\hline In 2020 & In $\mathbf{2 0 1 5}$ \\
\hline 1. Complex problem solving & 1. Complex problem solving \\
2. Critical thinking & 2. Coordinating with others \\
3. Creativity & 3. People management \\
4. People management & 4. Critical thinking \\
5. Coordinating with others & 5. Negotiation \\
6. Emotional intelligence & 6. Quality control \\
7. Judgment and Decision making & 7. Service orientation \\
8. Service orientation & 8. Judgment and Decision making \\
9. Negotiation & 9. Active listening \\
10. Cognitive flexibility & 10. Creativity \\
\hline
\end{tabular}

Source: (World Economic Forum, 2016)

The above table shows that some important skills in 2015 will shift or change significantly in 2020. The most changing skills are creativity, negotiation and active listening. While negotiation and flexibility are high on the list of skills for 2015, by 2020, these skills will rank down in the top 10 skills (John, 2016). The reason of this change, according to WEF (quoted in Nguyen Thao, 2017) is that machines will use a large amount of data and start making decisions on behalf of people. Also, active listening considered to be a current core skill, will completely disappear from the 10 skills of 2020. Intellectual emotional skills which are not included in the top 10 of these skills, will become one of the top skills needed. The list also implies that in order to be successful in the industry 4.0, workers should have new skills such as creativity, critical thinking, solving complex problems and high emotional intelligence. Therefore, the training of the above soft skills for workers has become an urgent issue and requires countries to change the education system, in which each student's ability to study by self is the key factor.

Generally, the review of the literature suggests that the industrial revolution 4.0 is expected to generate profound impacts, especially to the labor market, and that some of the existing skills will disappear or will change to necessary level. Scholars in the WEF (2006) show that three new skills that are critical to the workforce are: 1) Complex Problem Solving, 2) Critical Thinking, and 3) Creativity. Scholars have affirmed the importance and necessity of these three skills in education and training. These three skills do not seem to have been trained in our educational institutions. To address the gap between requirements of the industry 4.0 and the ability to adapt to this revolution, the paper aims to propose a model of training of the three skills because they are the most concerned points of the education. Having opportunity to practice these three skills through the learning process in the school, students may adapt themselves to the job requirements posed by the industry 4.0. The proposal of skill training model is mapped in the conceptual framework below. 


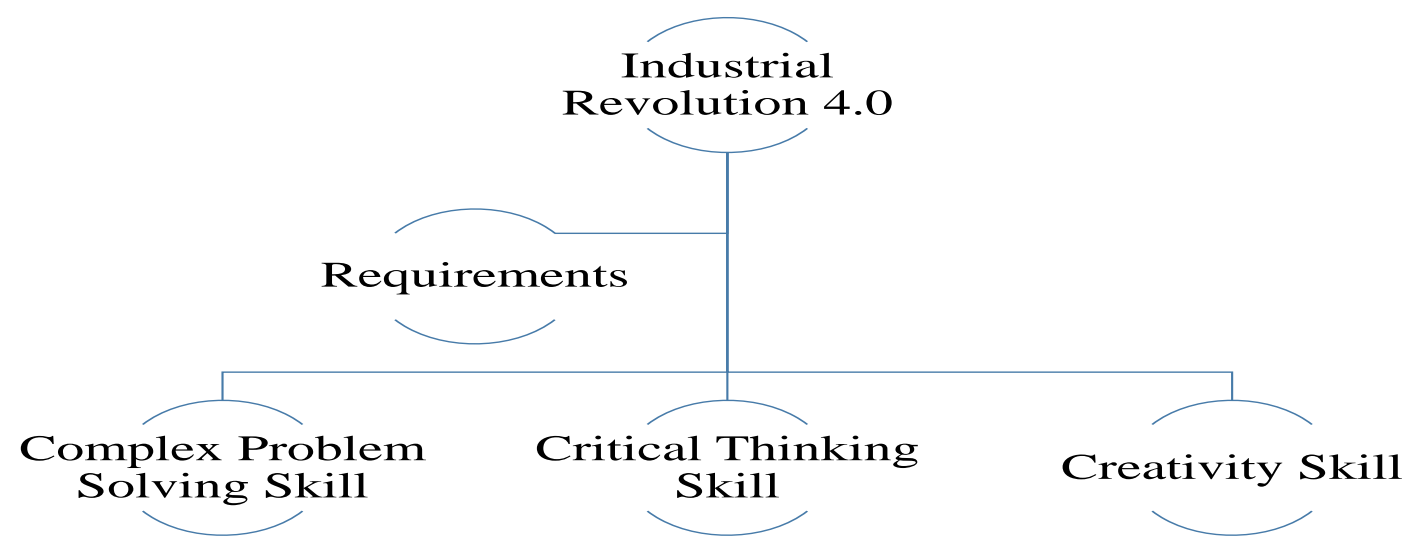

Conceptual Framework Of The Proposal

\section{Definition of Terms}

To have a better understanding of the proposal, the following terms in the conceptual framework above need to be clarified:

\section{Complex Problem-Solving Skills}

These are defined as the ability to solve complex problems. This process can be divided into the following steps: 1) Identify the problem; 2) Identify the causes; 3) Look for solutions; 4) Make a decision and put it in place; and 5) Evaluate feedback (Stephen Fetters, 2017). During the industry 4.0, robots are supposed to replace humans performing repetitive tasks with skills for a long time and never making mistakes. Software technology using algorithms is also replacing people. Algorithm is a mathematical formula for completing a well-defined task. Software technology can count, add, subtract, multiply, divide, search, compare, compile and analyze patterns with large amounts of data at a speed beyond human understanding. However, it is not a matter of which robots and software can change people, they can tell problems, and only humans can judge and solve. In this paper, complex problem-solving skills are understood as the students' capacity needed to solve new problems, unspecified issues in complex situations in the learning process. .

\section{Critical Thinking Skill}

This is defined as the ability to think clearly and reasonably about what to do or what to believe, including the ability to reflect and think independently. People with critical thinking skills can: 1). Understand the logical relationship between ideas; 2) Identify, build and evaluate arguments; 3) Detect common conflicts and mistakes in reasoning; 4) Solve problems in a systematic way; 5) Identify the rationality and importance of ideas; and 6) Evaluate one's own belief and values (Joe. Y. F. Lau, 2011). During the industry 4.0, robots and software technology are changing people at an increasing speed. A skill that technology does not have is judgment or critical thinking skills. In the context of this paper, critical thinking is understood as the students' ability to: 1) Read, listen and write a problem with critical thinking; 2) Identify useful and non-useful information; 3) Analyse the logical relationship between ideas in the relevant information system; and 4) Make the right decision.

\section{Creativity Skill}

This is defined as: 1) The ability to think outside the box; 2) Coming up with something that's never been done before; 3) Applying old methods in new ways; and 4) Perceiving the world in new ways (Stephen Fetters, 2017). During the industry 4.0, creativity is one of the top concerns. 
With the rapid growth of new technology products and new ways of working, robots may replace people in some jobs, but they do not have skill of creativity. In the context of this article, creativity skill refers students' ability to have new way of learning, performing tasks and perceiving problems in learning process.

\section{Proposal For A Proposal For A Training Model Of Skills}

The model consists of 2 modules with 6 sessions. Each session is expected to last in 60-90 minutes. Please see Table below for a detailed description of the modules.

\begin{tabular}{|c|c|c|}
\hline $\begin{array}{c}\text { Module } \\
1\end{array}$ & $\begin{array}{c}\text { Session } \\
\text { titles }\end{array}$ & PRELIMINARY \\
\hline \multirow[t]{2}{*}{$\begin{array}{c}\text { Day } \\
1\end{array}$} & $\begin{array}{l}\text { Assessme } \\
\mathrm{nt}\end{array}$ & $\begin{array}{l}\text { Objectives: Rate students' knowledge of the industry } 4.0 \\
\text { Strategy: Students are asked to complete questionnaires about } \\
\text { behaviour of technology and awareness about the industry } 4.0 \text { by } \\
\text { Barbara Motyl (2017). }\end{array}$ \\
\hline & $\begin{array}{l}\text { Prepare } \\
\text { the } \\
\text { participan } \\
\text { ts }\end{array}$ & $\begin{array}{l}\text { - Getting to know each other } \\
\text { - Orientation on confidentiality } \\
\text { - Establishing the rules during the sessions } \\
\text { - Expectations } \\
\text { - Getting nick names or emails for later feedbacks }\end{array}$ \\
\hline
\end{tabular}

Day 2 Educate Objectives: To enable students to understand and recognize the the $\quad$ importance of the industry 4.0 in life and future jobs.

Participan Expected outcomes: At the end of the session, students is able to ts understand the revolution's benefits, opportunities and challenges. Strategy:

TEACHERS' ACTIVITIES: present the industry 4.0 content

a. Core element of industry 4.0: Artificial Intelligence (AI), Internet of Things (IoT) and Big Data

b. Research areas of industry 4.0: 1) In biotechnology, the Industry 4.0 studies to create leaps in Agriculture, Fisheries, Medicine, food processing, environmental protection, renewable energy, chemistry and materials; 2) In physics, it is searching to create new generation robots, 3D printers, self-driving cars, new materials (grapheme, skyrmions ...) and nano technology.

c. Skills required in industry 4.0

STUDENTS' ACTIVITIES: students are required to work on the following questions:

a. Awareness questions: as a student, how important is industry 4.0 to your current studying and future career?

b) Skill-oriented questions: in your opinion, what skills that robots and technology cannot replace people and skills you need to train from now in the university so that you can later be adaptive to employment requirements in the industry 4.0 ?

c) Sharing / group discussion: students will be invited to share and discuss work results from the 2 questions above. 


\begin{tabular}{|c|c|c|}
\hline $\begin{array}{c}\text { Module } \\
2\end{array}$ & $\begin{array}{c}\text { Session } \\
\text { titles }\end{array}$ & SKILL TRANING \\
\hline $\begin{array}{c}\text { Day } \\
\mathbf{3}\end{array}$ & $\begin{array}{l}\text { Complex } \\
\text { problem } \\
\text { solving }\end{array}$ & 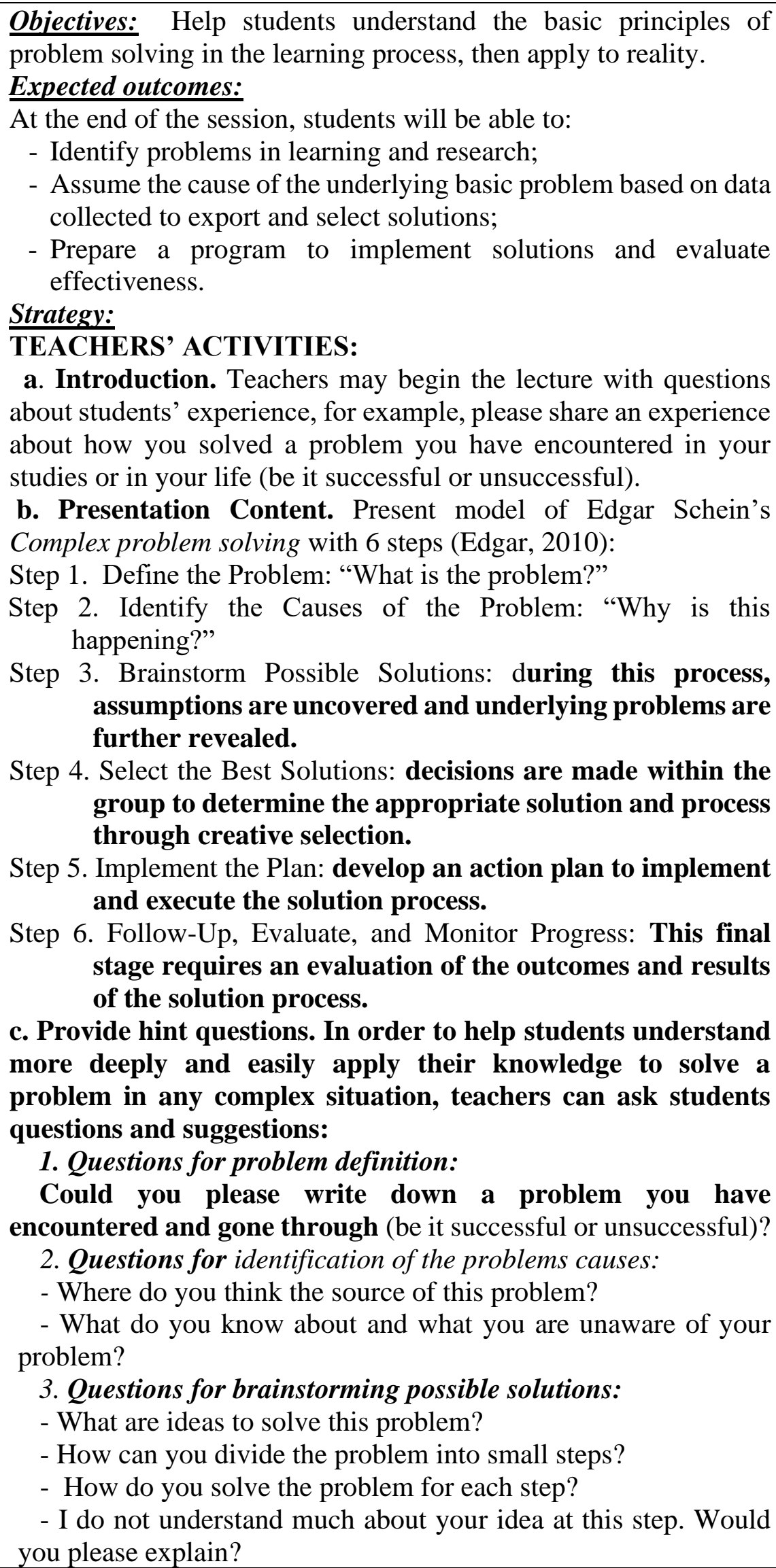 \\
\hline
\end{tabular}




\section{Questions for best solution selection:}

- In the above solutions, which solution do you think is feasible?

Please rank the feasibility of the solutions.

- What could possibly go wrong if we do this?

5. Questions for the plan implementation:

- Can you tell me when you can start solving the problem?

- How long will it take you to solve the problem?

- Who can be your resources of support?

- What information channels do you use to solve the problem?

Please write this information in an action plan for easy monitoring.

6. Questions for Follow-Up and Evaluation:

- Do your decisions meet your expectations?

- If you need to change something in the action plan, what details will you change?

STUDENTS' ACTIVITIES :

a) Group discussion with question below:

Are the problem-solving steps in the lecture different from how you and your team members usually do?

b) Individual practice

Exercise 1: If you solve again the problem you shared at the beginning of the session, how will you do it?

Exercise 2: your teacher gives you a topic and ask you to present it after two weeks from now, but you have difficulties because it is very new to you. Please solve your problems.

Note: Do not forget to make use of internet of things as well as knowledge and suggestions in the lesson.

$\begin{array}{cc}\text { Day } & \text { Critical } \\ 4 & \text { thinking }\end{array}$

Objectives: Help students develop critical thinking skills during their learning process.

Expected outcomes: at the end of the lesson, students are expected to be able to:

- Read, listen and write a problem with critical thinking;

- Identify useful and non-useful information, right or wrong information;

- Analyze the logical relationship between ideas in the relevant information system.

- Make convincing conclusions

\section{Strategy:}

\section{TEACHERS' ACTIVITIES:}

\section{a. Introduction.}

- Invite students to share their knowledge of an area that they have learned / experienced;

- Encourage them to try to make comments about what they know, their views on that knowledge, including misperceptions.

Examples:

1. Have you used any internet applications to connect things and people, for examples: WhatsApp, WeChat, Facebook Messenger, and others?

2. Do you think that the above applications have the same function as connection? 
3. Which of the applications is most useful to you?

- Invite students to share some personal views about the above questions and provide evidence of their arguments.

\section{b. Presentation Content}

Suggestion Question (will be used throughout the session): Do you think that a trusted friend provides accurate information. Do you have proof of that?

Presentation: Pearson's Critical Thinking-RED Model of 3 step (Pearson, 2018):

Step 1: Recognize Assumptions

We easily believe what others say or comment and are easily convinced that what they say is true and sometimes there is no sufficient evidence. Therefore, in order to have a correct view of a problem or a right decision, it is necessary to identify the logical gap in words and subjective opinions that are disguised as true.

Definition. Assumption recognition is understood as the ability to separate objective reality from subjective opinions.

Skills for assumption recognition: Check the information provided by asking yourself, or listen to what others say or associate similar situations that you have experienced about.

Questions to help students recognize assumptions:

\begin{tabular}{|c|c|}
\hline $\begin{array}{l}\text { Sample questions for assumption } \\
\text { recognition }\end{array}$ & $\begin{array}{l}\text { Suggestion questions for you } \\
\text { to answer the question from } \\
\text { the start of the lesson }\end{array}$ \\
\hline $\begin{array}{l}\text { - What are you assuming? } \\
\text { - Can you make another } \\
\text { alternative assumption? } \\
\text { - How do you argue for this } \\
\text { assumption? } \\
\text { - Do other people have same } \\
\text { assumption as your do? } \\
\text { - What information is important } \\
\text { and relevant to your } \\
\text { assumptions? } \\
\text { - What's missing? Is there any } \\
\text { information that needs to be } \\
\text { included? }\end{array}$ & $\begin{array}{l}\text { - I assume that the friend I } \\
\text { trust provide accurate } \\
\text { information. } \\
\text { - Do I have any other } \\
\text { assumptions? } \\
\text { - Do other people think like } \\
\text { me? } \\
\text { - How do I prove the } \\
\text { assumption that a trusted } \\
\text { friend provides accurate } \\
\text { information? } \\
\text { - Do I have any experience in } \\
\text { the case of assumption? }\end{array}$ \\
\hline
\end{tabular}

Note: The answers of questions above will offer wide information because there is a lot of evidence and many views around to evaluate the problem.

\section{Step 2: Evaluate Arguments}

In the age of information explosion, we often have trouble analysing information because: on the one hand, we receive conflicting sources of information, on the other hand we let them intervene or just listen to what I like to hear, or is familiar. In order to have objective and accurate information, it is necessary to have reasoning skills to make accurate am argument evaluation which helps us change our opinion when the evidence shows that it is something necessary to do. 
Definition. Reasoning is understood as assessing information with accompanying evidence to draw conclusions about an assumption (a logical conclusion). Evidence is often found in editorials, course reports, scientific journals, radio.

Skills for assumption recognition: including

- Evaluate information by asking questions with accompanying evidence to find out if feelings affect the argument; and

- Assessing the level of prejudice and feeling of yourself or others' that affect your objectivity.

Sample questions for $\begin{aligned} & \text { Sample questions for yourself to } \\ & \text { assumption recognition } \\ & \text { answer the question from the } \\ & \text { start of the lesson }\end{aligned}$

- Can you explain the reason for -What reason do I believe a that? trusted friend will provide - Are these reasons sufficient? accurate information?

- Is there any evidence of that? - Are those reasons sufficient?

- How can I find out if that is - Is there any evidence that the true? trusted friend provided the

- How do people talk about this? correct information?

- What experience did I have about this?

- What do other people say about the accuracy of the information my friend provides and how many people?

- Does anyone have ideas against me and what values are in their arguments?

- Was I previously provided accurate information by my friend?

Note: Being able to answer the above questions, students can make a more accurate conclusion about the assumption.

Step 3. Draw Conclusions

Making conclusions is the result of the work of the previous two steps. When thinking critically, the surrounding issues will become clear and students can make difficult decisions or know how to overcome difficult problems.

Skills for drawing conclusions

After reviewing all the hypothetical facts and events, ask questions while making conclusions:

-What is the best conclusion?

- Can there be any other conclusions?

- What new information can change my conclusions?

- Does this conclusion seem reasonable based on my common sense and experience?

-What are the implications of this conclusion?

\section{STUDENTS' ACTIVITIES:}

a) Discussion (group) with the question: what do you learn from the 3-step model in critical thinking? 
b) Practice (individual).

Question: You think that in the industrial revolution 4.0, robots and technology can change people and therefore affect your future work?

Requirements: Use your learned knowledge and question system presented to find information with evidence to argue and make your own decisions.

Materials: Refer to industrial revolution 4.0 documents from editorials, course reports, scientific journals, broadcasting and internet of things.

\begin{tabular}{|c|c|c|}
\hline $\begin{array}{c}\text { Day } \\
5\end{array}$ & $\begin{array}{l}\text { Creativity } \\
\text { skill }\end{array}$ & $\begin{array}{l}\text { Objectives: To help students develop creativity skill in learning } \\
\text { process to be adaptable to the challenges of the revolution. } \\
\text { Expected outcomes: } \\
\text { At the end of the session, students are expected to: } \\
\text { - know how to use imagination, } \\
\text { - be able to interact / collaborate with people inside and outside } \\
\text { the group, } \\
\text { - have ability to build new ideas, and } \\
\text { - perform tasks in a new way } \\
\text { Strategy: } \\
\text { TEACHERS' ACTIVITIES: } \\
\text { a. Introduction: lecturers suggest some questions that stimulate } \\
\text { students' creative ideas: } \\
\text { 1. What would you do if you had to do a job you didn't study in } \\
\text { school? } \\
\text { 2. How will you handle if your career is no longer timely and } \\
\text { will disappear in the next few years. } \\
\text { 3. Some other questions with same purpose may be asked. } \\
\text { b. Presentation content } \\
\text { 1. Definition. Creativity refers to ability to: } \\
\text { - Think, give a new idea to do a job that has never been done } \\
\text { before } \\
\text { - Recognize problems in new ways and apply old methods in new } \\
\text { ways. } \\
\text { 2. Skills for creativity: } \\
\text { 2.1. The Osborne-Parnes Creative Process (cited in Halil } \\
\text { Özmen, 2006). Teachers brings students to the creative process } \\
\text { of work according to the Osborne-Parnes model in the table } \\
\text { below which will tell students what to do at each immediate step } \\
\text { in order to eventually produce one or more creative, workable } \\
\text { solutions. A unique feature is that each step first involves a } \\
\text { divergent thinking phase in which one generates lots of ideas } \\
\text { (facts, problem definitions, ideas, evaluation criteria, } \\
\text { implementation strategies), and then a convergent phase in } \\
\text { which only the most promising ideas are selected for further } \\
\text { exploration. }\end{array}$ \\
\hline
\end{tabular}




\begin{tabular}{|c|c|c|}
\hline 6 Steps & Objectives & Guideline Questions \\
\hline $\begin{array}{l}\text { 1. Objective } \\
\text { Finding }\end{array}$ & $\begin{array}{l}\text { Identify goal, } \\
\text { wish and } \\
\text { challenge }\end{array}$ & $\begin{array}{l}\text { What is the goal, wish, or } \\
\text { challenge upon which you } \\
\text { want to work? }\end{array}$ \\
\hline 2. Fact-finding & $\begin{array}{l}\text { Data } \\
\text { gathering }\end{array}$ & $\begin{array}{l}\text {-What's the situation or } \\
\text { background? } \\
\text { - What are all the facts, } \\
\text { questions, data, feelings that } \\
\text { are involved }\end{array}$ \\
\hline $\begin{array}{l}\text { 2. Problem } \\
\text { finding }\end{array}$ & $\begin{array}{l}\text { Clarify the } \\
\text { problem }\end{array}$ & $\begin{array}{l}\text { - What is the problem that } \\
\text { really needs to focus on? } \\
\text { - What is the concern that } \\
\text { really needs to be addressed? }\end{array}$ \\
\hline 4. Idea-finding & $\begin{array}{l}\text { Generate } \\
\text { Ideas }\end{array}$ & $\begin{array}{l}\text { What are all the possible } \\
\text { solutions for how to work with } \\
\text { the } \\
\text { problem? }\end{array}$ \\
\hline $\begin{array}{l}\text { 5. Solution- } \\
\text { finding }\end{array}$ & $\begin{array}{l}\text { Select \& \& } \\
\text { Strengthen } \\
\text { Solutions }\end{array}$ & $\begin{array}{l}\text { How can you select } \\
\text { the solutions to know which } \\
\text { one will work best? How can } \\
\text { you strengthen the } \\
\text { solution? }\end{array}$ \\
\hline $\begin{array}{l}\text { 6. Acceptance } \\
\text { finding }\end{array}$ & $\begin{array}{l}\text { Plan for } \\
\text { Action }\end{array}$ & $\begin{array}{l}\text { What are all the action steps } \\
\text { that need to take place in order } \\
\text { to implement your solution }\end{array}$ \\
\hline
\end{tabular}

2.2. Questions to stimulate creative ideas at each stage:

Objective Finding-Use following questions prepared by Parnes in 1981 to prod students' thinking:

-What would you like to get out of life?

-What are your goals, as yet unfilled?

- What would you like to accomplish, to achieve?

- What would you like to have?

- What would you like to do?

- What would you like to do better?

- What would you like to happen?

- In what ways are you inefficient?

-What would you like to organize in a better way?

- What ideas would you like to get going?

- What relationship would you like to improve?

-What would you like to get others to do?

- What takes too long?

- What is wasted?

- What barriers or bottlenecks exist?

- What would you wish you had more time for?

- What do you wish you had more money for?

-What makes you angry, tense or anxious?

- What do you complain about? 
Fact finding- use who, what, when, where, why and how questions

- Who is or should be involved?

- What is or is not happening?

-When does this or should this happen?

- Where does or does not this occur?

- Why does it or does not it happen?

- How does it or doesn't it occur?

Problem-finding-Listing alternative definitions of the problem. One principle of creative problem solving is that the definition of a problem will determine the nature of the solutions.

- What is the real problem?

- What is the main objective?

-What do you really want to accomplish?

- Why do I want to do this?

Idea-finding- The divergent-thinking, brainstorming stage. This is where a variety of idea-generation ("creativity") techniques can be used. Ideas are freely proposed without criticism or evaluation, for each of the problem definitions accepted in the second stage.

Solution-finding- Three related steps:

1. Criteria for evaluation listed

2. The ideas are evaluated (evaluation matrix is useful)

3 . One or more of the best ideas are selected

Criteria might include:

- Will it work?

- Is it legal?

- Are the materials and technology available?

- Are the costs acceptable?

- Will the public accept it?

- Will higher-level administrators accept it?

Acceptance finding- ways to get the ideas into action. This may involve creating an action plan, which is a plan containing specific step to be taken and a timetable for taking them.

\section{STUDENTS' ACTIVITIES:}

a) Discussion (group)

Today, your group is going to present a topic (on PowerPoint), but 10 minutes before the presentation schedule, the group was informed of the power outage. How will you handle the group's work?

Requirements:

1. Illustrate the steps to solve problems by diagram

2. The groups is required to make cross-review, discussing similarities and differences in the implementation steps between the groups. Do the similarities and differences create any new value (what is that value? For example, the other group finished in shorter time but efficiently, and easily to understand, and others ...)

\section{b) Practice (individual or group)}

Choose 1 of 2 topics:

Topic 1: Make an action plan for a career / job you / your group is aiming for. 
Topic 2: You have a desire to start a business, but you see a lot of friends who set up businesses, but many of them have not been able to "celebrate" first year of foundation. However, you still have the ambition to start a business, please create your start-up plan based on the knowledge you have acquired.

Note: apply the steps in the creative model to plan.

\begin{tabular}{cll}
\hline Day & Program & - Groups present career plans as assigned \\
$\mathbf{6}$ & evaluatio & - Share experiences about the whole program \\
& $\mathrm{n}$ & - Grant awards and certificates of completion of training courses \\
& & - Evaluate changes of students after completing the training. \\
\hline
\end{tabular}

\section{Conclusions and Recommendations}

The industrial revolution 4.0 is predicted to have profound and multi-faceted impacts on the world economy in the years to come, which can fundamentally change the mode of production, business, consumption, labor market, in which education is exceptional. The problem in the future is not the lack of jobs, but of skills to meet the demands that new jobs pose. The paper attempts to propose a training model, which focuses on the three most important skills as required by the revolution. The model proposed aims to add a tool to the field of education, specifically for educators, teachers, academic advisors and students. Because these skills may help students adapt and do well the jobs that machines and technology cannot replace. The program includes 2 modules as mentioned. This is just a proposal; therefore educators, teachers, vocational counselors and students are encouraged to experiment to explore if the program is effective. Future researchers are also encouraged to apply this program for evaluation to reinforce its effectiveness.

\section{References}

Andreja Rojko (2017). Industry 4.0 Concept: Background and Overview. Special Focus Paper, International Journal of Interactive Mobile Technologies (IJIM), Vol 11, No 5.

Barbara Motyl (2017). How Will Change the Future Engineers' Skills in the Industry 4.0 framework? A questionnaire surveys. Retrieved from https://www.researchgate.net/profile/.../142-FAIM2017-Motyl.pdf

Đào Quang Vinh (2017). Labor, Employment and Social Security Issues in A Digital Era, Training Materials "International Integration in the Field of Labor - Society and Cooperation on Labor and Social Welfare in ASEAN", July 18-28, 2017, Ho Chi Minh City.

Egham (2015). What Is Industry 4.0 and What Should CIOs Do About It? Retrieved from http://www.gartner.com/newsroom/id/3054921.

Edgar H Schein (2010). Organizational culture and leadership. Publisher: San Francisco: Jossey-Bass; $4^{\text {th }}$ Edition, ISBN: 0470190604

Ernst \& Young LLP (2017). Leapfrogging to Education 4.0: Student at the core. Retrieved from https://www.ey.com/Publication/vwLUAssets/ey-leap-forgging/\$File/ey-leapforgging.pdf

Halil Özmen (2006). Creative Problem Solving. Retrieved from http://members.optusnet.com.au/ charles57/Creative/Brain/cps.htm

Nguyễn Cúc (2017). Impact of Industrial Revolution 4.0 on higher education institutions in Vietnam and policy implications for Vietnam. Communist Review. Retrieved from http://www.tapchicongsan.org.vn/Home/Van-hoa-xa-hoi/2017/46536/Tac-dong-cuacuoc-Cach-mang-cong-nghiep-40-doi-voi-co.aspx. 
Nguyễn Thảo (2017). Success at Industrial Revolution 4.0: Essentials of Creativity Capacity. Retrieved from http://vietnamnet.vn/vn/giao-duc/khoa-hoc/nguoi-lao-dong-muonthanh-cong-trong-nen-cong-nghiep-4-0-phai-co-nang-luc-sang-tao-390060.html

Joe. Y. F. Lau (2011). An Introduction to Critical Thinking and Creativity: Think More, Think Better. John Wiley \& Sons, inc., Publication, ISBN: 978-0-470-19509-3.

John Lodder (21/02/2016), The Fourth Industrial Revolution and the Education System, how to respond? Retrieved from https://www.linkedin.com/pulse/fourth-industrialrevolution-education-system-how-respond-john-lodder.

Priya Sharma (2019). Digital Revolution of Education 4.0. International Journal of Engineering and Advanced Technology (IJEAT), ISSN: 2249 - 8958, Volume-9 Issue2.

Pearson's RED Critical Thinking Model (2018). Retrieved 14/08/2018, from https://www.thinkwatson.com/the-red-model/red-critical-thinking-model.

Scientix (2017), the Unknown Impact of the Fourth Industrial Revolution in Education. Retrieved from http://blog.scientix.eu/2017/07/the-unknown-impact-of-the-fourthindustrial-revolution-in-education/\#_ftn1

Stephen Fetters (2017). Successful Content Marketing. Retrieved from https://successfulcm.com/

Schwab Klaus (2016). The Fourth Industrial Revolution; World Economic Forum: Geneva, Switzerland, ISBN 9781944835002.

World Economic Forum (2016). The Future of Jobs. Retrieved from http://reports.weforum.org/future-of-jobs-2016 